УДК 342.9

DOI: https://doi.org/10.54929/pmtl-issue1-2021-13

\title{
ШЛЯХИ УДОСКОНАЛЕННЯ СИСТЕМИ КІБЕРБЕЗПЕКИ В УКРАЇНІ
}

\section{WAYS TO IMPROVE THE CYBERSECURITY SYSTEM IN UKRAINE}

\author{
Яковенко Ю. Л. \\ кандидат історичних наук, \\ кафедра історії України та правових дисциплін \\ Донбаський інститут техніки та менеджменту \\ ЗВО « «іжнародний науково-технічний \\ університет імені академіка Юрія Бугая» \\ ORCID: 0000-0002-3281-4100
}

Деркаченко Ю. В. кандидат юридичних наук, кафедра права «Міжнародний науково-технічний університет імені академіка Юрія Бугая» ORCID: 0000-0002-3019-9730

Кухтик С. В. кандидат юридичних наук, кафедра права «Міжнародний науково-технічний університет імені академіка Юрія Бугая»

ORCID: 0000-0002-2738-5866

Березовський Д. О. кандидат наук з державного управління, кафедра менеджменту та публічного адміністрування «Міжнародний науково-технічний університет імені академіка Юрія Бугая»

ORCID: 0000-0001-9529-8505

Yuliia Yakovenko

$\mathrm{PhD}$ in History, Department of Law, Donbass Institute of Technology and Management

Yuliia Derkachenko

$\mathrm{PhD}$ in Law, associate professor, Department of Law, Academician Yuriy Bugay International Scientific and Technical University

Stanislav Kukhtyk

$\mathrm{PhD}$ in Law, associate professor, Department of Law, Academician Yuriy Bugay International Scientific and Technical University

Danylo Berezovskyi

$\mathrm{PhD}$ in Public Administration, associate professor, Department of Management and Public Administration, Academician Yuriy Bugay International Scientific and Technical University

Досліджено нормативно-правову базу кібербезпеки України. У статті розәлядаються поняття кіберпростір, кібербезпека, кіберзагроза та кіберінтервенція. Проаналізовано наукові праці вітчизняних та зарубіжних дослідників із питань забезпечення кібербезпеки. Процес діджиталізації в Україні зумовлює необхідність нового формату взаємодії органів місцевого самоврядування з громадянами. Наголошено на необхідності забезпечення компетенції цифрової грамотності в органах місцевого самоврядування. Проаналізовано проблеми в процесі створення безпечного кіберпростору в Україні. Встановлено, що одним із можливих шляхів до створення безпечного кіберпростору $є$ розвиток відповідної освіти в Україні. Громадяни мають бути забезпечені знаннями щодо захисту особистих даних, продуктів власної творчості, ділової інфрормації та мати відповідні вміння щодо безпечного використання інформаційного середовища. Доведено важливість поширення комп'ютерної грамотності серед студентів. Виявлено необхідність подальшої роботи з конкретизації Стратегії кібербезпеки України. Ключові слова: кібербезпека, кіберпростір, кіберзахист, кіберінтервенція, кіберзагроза, діджиталізація, інфрормаційні технології.

Исследована нормативно-правовая база кибербезопасности Украины. В статье рассматриваются понятия киберпространство, кибербезопасность, киберугрозы и киберинтервенция. Проанализированы науч- 
ные труды отечественных и зарубежных исследователей по вопросам обеспечения кибербезопасности. Процесс диджитализации в Украине вызывает необходимость нового формата взаимодействия органов местного самоуправления с гражданами. Отмечена необходимость обеспечения компетенции цифровой грамотности в органах местного самоуправления. Проанализированы проблемы в процессе создания безопасного киберпространства в Украине. Установлено, что одним из возможных путей к созданию безопасного киберпространства является развитие соответствующего образования в Украине. Граждане должны быть обеспечены знаниями по защите личных данных, продуктов собственного творчества, деловой информации и иметь соответствующие умения по безопасному использованию информационной среды. Доказана важность распространения компьютерной грамотности среди студентов. Выявлена необходимось дальнейшей работы по конкретизации Стратегии кибербезопасности Украины. Ключевые слова: кибербезопасность, киберпространство, киберзащита, киберинтервенция, киберугрозы, диджитализация, информационные технологии.

Information technology in the modern world is evolving very fast. The course of digitalization in Ukraine necessitates the provision of digital literacy of the population. However, the level of human insecurity in the infospace is growing. Cyber threats have become commonplace. Since cybersecurity is part of national security, it is not surprising that its current state is a condition for the stable development of the country. In this case, creating an effective cyber defense system becomes a priority in Ukraine. The need to find optimal ways to improve the cybersecurity system in Ukraine and their implementation requires scientists to work in this direction. It should be understood that the cybersecurity system must be in the process of continuous improvement. Only with proper attention to cybersecurity is it possible to achieve the required level of efficiency in the development of the state. The purpose of this article is to explore ways to improve the domestic cybersecurity system. The normative-legal base of cybersecurity of Ukraine is investigated. The article considers the concepts of cyberspace, cybersecurity, cyber threat and ultimate intervention. Scientific works of domestic and foreign researchers on cybersecurity are analyzed. The process of digitalization in Ukraine necessitates a new format of interaction between local governments and citizens. The need to ensure the competence of digital literacy in local governments is emphasized. Problems in the process of creating safe cyberspace in Ukraine are analyzed. It is established that one of the possible ways to create a safe cyberspace is the development of appropriate education in Ukraine. Citizens must be provided with knowledge on the protection of personal data, products of their own creativity, business information and have the appropriate skills for the safe use of the information environment. The importance of spreading computer literacy among students has been proven. The need for further work on the specification of the Cyber Security Strategy of Ukraine has been identified. The cyber defense system is nationwide, so Ukrainian scientists should conduct further research in this area. Key words: cybersecurity, cyberspace, cyber protection, cyber intervention, cyber threat, digitalization, information technologies.

Постановка проблеми. Сучасні інформаційні технології розвиваються швидко. Одночасно і зростає рівень незахищеності людини в інфопросторі, який став невід'ємною частиною життя, каналом поширення інфрормації, платформою управління. Кіберзагрози та кібератаки стали звичайним явищем в сучасному світі. Кібербезпека - частина національної безпеки. Ї̈і стан - умова стабільного розвитку країни. Тому постійне вдосконалення системи кіберзахисту - одна із актуальних сучасних завдань держави. Шляхів такого вдосконалення існує достатньо. Важливою $є$ міжнародна співпраця в обміні досвідом між різними країнами світу стосовно створення безпечного кіберпростору. В умовах посилення кібератак та інформаційної війни для України така співпраця $є$ необхідною, а робота зі створення ефективної системи кіберзахисту має проходити пришвидшеними темпами.

Аналіз останніх досліджень і публікацій. Дослідженням питань кіберзагроз та кібербезпеки науковці приділяють все більше уваги. Аналіз останніх досліджень та публікацій демонструє, що певними питаннями забезпечення кібербезпеки в Україні у своїх працях займалися науковці Валюшко І.О., Бакалінська О., Бакалінський О. Хоббі Ю. Грицюк, Ю.І., Трофименко О., Прокоп
Ю., Логінова Н., Задерейко О., Янковський, О. Чибиряк, М.С., Федоровська, Н.В. та інші. Проблемами кібербезпеки в $€ С$ та країнах-членах присвячено праці Бойко В.Д., Василенко М.Д., В.Б. Гавриляк, Кухаренко С.В., Кавин С.Я., Рижков М. М., Рубан А. та інші. Вважається, що кіберпростір дуже скоро стане новим полем для війн в сучасному світі, а рівень обороноздатності країни буде визначатись за показниками якості та ефективності кіберзахисту. Тому дуже важливо знайти оптимальні шляхи удосконалення системи кібербезпеки в Україні та забезпечити їх впровадження.

Формулювання цілей статті (постановка завдання). Метою статті $€$ дослідження шляхів удосконалення вітчизняної системи кібербезпеки. Для цього слід виконати ряд завдань.

Виклад основного матеріалу дослідження. Проблема кібербезпеки є актуальною, такою, що постійно обговорюється у наукових колах.

Вперше поняття «кіберпростір» було використано у 1980-х роках $[1,118]$. Кіберпростір - це нове середовище, яка виникла внаслідок фрункціонування інформаційних, телекомунікаційних та інформаційно-телекомункаційних систем; нова сфера, яка не існує в фізичній формі, але передбачає активну взаємодію осіб, програмно- 
го забезпечення та послуг у мережі Інтернет [2].

Кібербезпека - це захищеність важливих інтересів людини, суспільства і держави в кіберпросторі, яка забезпечує сталий розвиток інформаційного суспільства, цифрового середовища, швидке виявлення та реагування на загрози безпеці $[3,37]$. Це збереження конфіденційності та цілісності інфрормації у кіберпросторі [2]. Таким чином, кібербезпека стосується захисту прав свобод громадян в ході пересування кіберпростором $[3,38]$ та національних інтересів держави.

Кіберзахист - це система організаційних, правових, інженерно-технічних та інших заходів, спрямованих на запобігання кіберзагрозам, ліквідацію їх наслідків, відновлення надійності інформаційних систем [3, 39].

Деякі дослідники вважають, що ми вступили в фразу кібервійн (кіберінтревенції), оскільки фракти небезпечних дій в кіберпросторі зростають кількісно та якісно [4, 327]. Кіберінтервенція - це комплекс суспільно небезпечних дій, які наносять шкоду важливим сфрерам існування держави та суспільства $[4,329]$. Різні сектори державного, економічного, суспільного життя стають більш уразливими до подібного роду дій, потребують захисту. Кіберзлочинність набула характеру транснаціонального [4, 329]. Кібергрупи та окремі хакери активізуються, здійснюють атаки на урядові та приватні сайти, порушують роботу інфоормаційних ресурсів [4, 332]. Поширився кардінг - фрінансові злочини в кіберпросторі [4, 331]. Серед наслідків кіберінцидентів різного характеру завдання удару авторитету держави, розповсюдження неправдивої інформації, дезорієнтація населення, збір цінної інформації, порушення фрункціонування сайтів, комп'ютерних систем, об'єктів критичної інфраструктури [5].

У 2014 році в Україні було зафріксовано 216 кібератак ззовні, більша частина я яких була здійснена на державні установи. У 2015 році кількість таких атак значно збільшилась [1, 120]. Кожен третій комп'ютер в Україні заражений шкідливими програмами [7, 155]. На одне з 36 мобільних пристроїв встановлені небезпечні додатки. Один з 13 пошукових запитів призводять до шкідливих програм [6]. Тому одним із важливих завдань держави $€$ встановлення таких рівнів захисту інфрормації, як: запобігання (надання доступу виключно персоналу), виявлення (раннє виявлення злочинних дій), обмеження (зменшення масштабів наслідків злочинів), відновлення (можливість відновлення втраченої інформації) [5Міністерство]. Створення безпечного кіберпростору передбачає впровадження системи заходів на декількох рівнях одночасно: політичному, юридичному, міжнародному, освітньому, науково-технічному $[7,151]$.
3 кожним роком органи публічного управління дедалі більше залежать від технологій та переводять свою діяльність у цифровий світ. Постає проблема якісної взаємодії з громадянами, що потребує створення нового формату відносин у рамках процесу діджиталізації в Україні. Кіберзагрози несуть реальні ризики та зумовлюють орієнтацію на цифрову грамотність в публічному управлінні. Здатність ефрективно використовувати сучасні цифрові технології - важливе вміння сучасного державного службовця. В умовах децентралізації важливим є й забезпечення компетенції цифрової грамотності в органах місцевого самоврядування. Курс на цифрову грамотність має забезпечити управлінців сучасними знаннями щодо уникнення небезпек в цифровому просторі, навичками зберігання конфіденційних даних та вміннями результативного вирішення критичних ситуацій за допомогою цифррових технологій.

Україна має орієнтуватись на кращі зарубіжні практики зі створення ефективної системи кіберзахисту, розширювати міжнародну співпрацю в цьому напрямку. У 2005 році була ратифікована Конвенція Ради Європи про кіберзлочинність від 2001 року. Вона була створена для запобігання поширення кіберзлочинності, вказує на необхідність співробітництва між державами з метою створення більш ефрективної системи захисту своїх інтересів у ході використання інфрормаційних технологій. Документ передбачає настання відповідальності за правопорушення проти конфріденційності та цілісності комп'ютерних даних та систем, комп'ютерні правопорушення. а також ті, які пов'язані із дитячою порнографрію та порушенням авторських й суміжних прав [8]. Це перша спроба у Європі об'єднати зусилля у боротьбі із кіберзлочинністю.

Після підписання Україною Угоди з ЄС наша держава взяла на себе зобов'язання впроваджувати чинне законодавство Союзу, в тому числі, у сорері кібербезпеки.

В Україні нормативно-правову базу кібербезпеки складають Конституція України, Стратегія кібербезпеки України, закони «Про інформацію», «Про захист інформації в інформаційно-телекомунікаційних системах», «Про захист персональних даних», «Про основні засади забезпечення кібербезпеки України» Постанова Кабінету Міністрів «Про затвердження Правил забезпечення захисту інформації в інформаційних, телекомунікаційних та інформаційно-телекомунікаційних системах» та інші.

Конституція України гарантує таємницю листування (стаття 31), не допускає збирання та поширення конфіденційної інформації про особу без ії̈ згоди (стаття 32) [9].

Закон України «Про інформацію» від 2 жовтня 
1992 року передбачає в якості напрямів державної політики в тому числі забезпечення інформаційної безпеки та розширення міжнародної співпраці в цій сфрері [10].

Закон України «Про захист інформації в інформаційно-телекомунікаційних системах» від 5 липня 1994 року визначає об'єктами захисту інформацію та програмне забезпечення для ії обробки. ЗУ вимагає повідомляти про спроби несанкціонованих дій с стосовно інформації 3 обмеженим доступом повідомляти спеціально уповноважені органи виконавчої влади з питань захисту інформації [11].

Закон України «Про захист персональних даних» від 1 червня 2010 року регулює правові відносини, пов'язані і захистом та обробкою персональних даних, які відбувається в тому числі із застосуванням автоматизованих засобів [12].

Стратегія кібербезпеки України від 15 березня 2016 року поставила за мету створення безпечного кіберпростору. Для цього необхідно сорормувати ефрективну національну система кібербезпеки, посилити спроможність суб'єктів сектору безпеки для боротьби із кіберзагрозами різного характеру, захистити важливі інформаційні ресурси [13].

Закон України «Про основні засади забезпечення кібербезпеки України» від 5 жовтня 2017 року визначає правові та організаційні основи забезпечення захисту інтересів людини, суспільства та держави у кіберпросторі, основні напрями державної політики у сорері кібербезпеки. Згідно зі статтею 4 ЗУ об'єктами кібербезпеки є конституційні права і свободи людини і громадянина, суспільство, держава, суверенітет та територіальна цілісність, національні інтереси, об'єкти критичної інфраструктури. Суб'єктами системи забезпечення кібербезпеки є: Президент України та Рада національної безпеки і оборони (загальна координація), Національний координаційний центр кібербезпеки як робочий орган РНБО, Кабінет Міністрів України, міністерства, місцеві державні адміністрації, правоохоронні та розвідувальні органи, Збройні Сили України та інші. Задані суб'єкти мають в межах своєї компетенції виявлять та реагують на кіберінціденти, обмінюються корисною інфрормацією, реалізують запобіжні заходи у сфрері кібербезпеки [14].

Закон України «Про національну безпеку України» від 21 червня 2018 року (стаття 31) підкреслює, що стратегія кібербезпеки є частиною системи національної безпеки і оборони [15].

Постанова Кабінету Міністрів України «Про затвердження Правил забезпечення захисту інформації в інформаційних, телекомунікаційних та інформаційно-телекомунікаційних системах» від 29 березня 2006 року була прийнята з метою захисту державних інформаційних ресурсів [16].
Постанова Кабінету Міністрів України «Про затвердження Загальних вимог до кіберзахисту об'єктів критичної інфрраструктури» від 19 червня 2019 року визначає організаційні, технічні та технологічні умови кіберзахисту об'єктів критичної інфрраструктури, які мають виконуватись всіма установами, які віднесені до цієї групи [17].

Серед Указів Президента Україні можна виділити № 242/2016 від 7 червня 2016 року про Національний координаційний центр кібербезпеки, який $є$ робочим органом при РНБО та має здійснювати аналіз у сфері кібербезпеки, брати участь у розробці галузевих індикаторів, у впровадженні механізмів обміну інформацією про кіберінциденти, прогнозувати та виявляти загрози, розробляти засади та пропозиції, узагальнювати міжнародний досвід [18].

Дослідники вказують на наявність багатьох проблем в процесі створення безпечного кіберпростору в Україні. Так, нормативну базу оцінюють як застарілу та неефективну [19]. Стратегію кібербезпеки України вважають занадто загальною, такою, яка не містить переліку конкретних кроків із забезпечення національної кібербезпеки зі строками реалізації, відповідальними органами [20; 4, 330]. І.О.Валюшко вважає головним недоліком Стратегії відсутність чіткого правового механізму залучення громадянського суспільства до забезпечення кібербезпеки [1, 122]. У Кримінальному кодексі України відсутнє поняття «кіберзлочин» [20; 4, 331]. Точаться дискусії навколо визначень понять «кіберзлочинність» та «кіберзахист» $[4,330]$. Деякі науковці наполягають на розробці додаткових нормативно-правових актів, які чітко визначать об'єкти критичної інфрраструктури, критерії створення переліку таких об'єктів, загальні вимоги до їх захисту, вимоги до проведення аудиту інформаційної безпеки та інші [2].

Також дослідниками підкреслюється, що більшість українських компаній не готові вчасно та швидко реагувати на кіберінціденти, не мають в штаті підготовлених спеціалістів. Відсутнє централізоване управління силами реагування, громадяни не мають достатнього рівня обізнаності в цих питаннях. Приватний бізнес не залучається до вирішення важливих питань кібербезпеки. Також дослідники бачать проблему в неефективності системи кіберрозвідки та низький рівень аудиту кібербезпеки [19].

Вирішення зазначених проблем потребують комплексного підходу. Система забезпечення протидії кіберзлочинності повинна мати загальнодержавний характер. Як зазначалось вище, вона має охоплювати одразу декілька напрямків активної діяльності: юридичний (вдосконалення законодавства), міжнародний (розширення міжнародної співпраці), освітній (просвітницькі кам- 
панії та відповідні навчальні програми у вищих навчальних закладах), політичний (активні дії 3 боку держави,спрямовані на захист свого інформаційного простору, цінностей), організаційний (передбачає активне державно-приватне партнерство), науково-технічний (вдосконалення інформаційних технологій) [7, 153-155]. Найкращі світові практики зі створення безпечного кіберпростору мають бути використані в нашій країні [20; 4, 331]. Доцільно запровадити галузеві регуляції, розроблені в інших державах [19].

Важливим кроком є створення єдиної інтелектуальної системи кібербезпеки для надійної охорони об'єктів у сфері державного управління та оборони. забезпечити її гнучкість та здатність швидко реагувати на загрози та зміни у технологіях [2]. Дослідник Ю. Грицюк вважає, що в умовах гібридної війни з Російською Федерацією необхідно створити центр кіберуправління у Збройних Силах України для забезпечення кібербезпеки на усіх рівнях, а також спеціальних підрозділів у ЗСУ, СБУ, Національній поліції та інших силових структурах [4, 333]. Слід розширити співпрацю з відповідними підрозділами НАТО [4, 333].

Одним із шляхів створення в Україні безпечного кіберпростору є розвиток відповідної освіти. Нашій державі потрібні висококваліфіковані спеціалісти у сорері боротьби із кіберзлочинами. Працівники прокуратури, слідчих органів, суду мають володіти кібертермінологією. Слід розвивати культуру роботи з електронними доказами [4, 331]. Окрім цього, усі громадяни, які щодня мандрують кіберпростором, повинні мати чіткі уявлення про безпеку, захист особистих даних, продуктів власної творчості, ділової інформації.

3 жовтня 2020 року Міжнародний науково-технічний університет імені академіка Юрія Бугая (м. Київ) та Донбаський інститут техніки та менеджменту МНТУ (м. Краматорськ) приєднались до проекту поширення кіберграмотності серед молоді, започаткованого Фондом цивільних досліджень та розвитку США (CRDF Global, 1995 р.). Він $€$ незалежною громадською некомерційною організацією, діяльність якого спрямована на утвердження миру та безпеки, забезпечення процвітання та сталого розвитку у світі. Фонд сприяє міжнародному науково-технічному співробітництву, організовує спільні дослідження та об'єднання науково-дослідних можливостей, допомагає в реалізації наукових проектів, підтримує освітні проекти. Основна місія CRDF Global - сприяння миру, процвітанню, економічній стабільності, нерозповсюдженню ядерної зброї, створення безпечних умов для життя та діяльності у різних куточках світу. Україна $€$ одним з партнерів Фонду цивільних досліджень та розвитку США.
Спільний проект CRDF Global з МНТУ та ДІТМ МНТУ реалізується з жовтня 2020 року [21]. Першим етапом співпраці стало онлайн-навчання 300 студентів на курсі «Базові правила безпеки у цифровому середовищі». Курс безкоштовний. Він присвячений основам кібергігієни, є досить популярним серед українських студентів, поширений в інших країнах світу. Курс доступною мовою розповідає про особливості кіберпростору, діяльність хакерів, дає роз'яснення стосовно інформації, на яку вони націлені, та рекомендації, яким чином краще захистити особисті дані, безпечно користуватись інформаційними ресурсами. Студенти різних спеціальностей, які долучились до курсу, успішно пройшли підсумкове тестування та отримали відповідні сертифікати. Після завершення першого етапу було проведено опитування. Воно показало, що студенти високо оцінили користь онлайн-курсу від CRDF Global, залишили позитивні відгуки стосовно подібної практики із підвищення рівня обізнаності у сорері кібербезпеки, дотримуються правил, про які дізнались під час навчання.

Отже, перший етап реалізації проекту був успішним, став яскравим прикладом важливості поширення комп'ютерної грамотності серед студентів, які не є спеціалістами в сфрері IT.

В рамках другого етапу реалізації проекту від CRDF Global були проведені робочі зустрічі та семінари з розробки та інтеграції освітніх курсів з поширення кіберграмотності в навчальні плани українських університетів.

Третій етап передбачає написання робочих програм, створення курсів лекцій та практичних занять для студентів, включення розроблених курсів у навчальні плани. На цьому етапі була підготовлена робоча програма та силабус з основ кібербезпеки для студентів з різних спеціальностей. яка включала перелік тем лекційних занять (два змістових модулі), тем семінарських занять, тем рефератів для індивідуальної роботи, список необхідної літератури. Триває робота над розробкою лекційного матеріалу, блоку тестових завдань, методичних вказівок до семінарських занять, індивідуальної роботи студентів, підготовкою наочного матеріалу для занять.

Висновок 3 цього дослідження. В новому середовищі, яким є кіберпростір, особливо актуальною проблемою для всіх сучасних країн $є$ кіберзахист та кібербезпека. XXI століття $є$ часом поширення кібератак та кіберзлочинів різного характеру. Тому метою України зараз є посилення кіберзахисту, захист прав і свобод громадян, державних інтересів. Нашою країною були ратифріковані відповідні міжнародні угоди, створена юридична база для запуску та фрунціонування системи кіберзахисту. Для її вдосконалення слід розширювати міжнародну співпрацю, запозичу- 
вати корисний досвід, об'єднувати зусилля. Напрямом подальшої роботи є конкретизація Стратегії кібербезпеки України, розробка додаткових нормативно-правових актів, швидка координація дій компетених органів. Система кіберзхисту має загальнодержавний характер, включаючи декілька напрямків: міжнародний, політичний, юридичний, організаційний, освітній. МНТУ ім. академіка Ю.Бугая та ДІТМ МНТУ з 2020 року реалізують проект спільно з Фондом цивільних досліджень та розвитку США, який пов'язаний саме з освітнім напрямком, забезпечуючи підвищення кіберграмотності серед студентської молоді.

\section{БІБЛІОГРАФІЧНИЙ СПИСОК:}

1. Валюшко І.О. Кібербезпека України: наукові та практичні виміри сучасності. Вісник НТУУ «КПІ» Політологія, соціологія. Право, 2016. 3/4(31/32), 117-124. https://doi.org/10.20535/2308-5053.2016.3/4(31/32).140496

2. Бакалінська О., \& Бакалінський О. Правове забезпечення кібербезпеки в Україні. Піприємництво, господарство і право, 2019. 9, 100-108. https://doi.org/10.32849/2663-5313/2019.9.17

3. Хоббі Ю. Право людини на кібербезпеку: проблеми визначення та гарантування. Юридичний вісник, 2020. 2, 37-43. https://doi.org/10.32837/yuv.v0i2.1701

4. Грицюк Ю.І. Кіберінтервенція та кібербезпека України: проблеми та перспективи їх подолання. Науковий вісник НЛТУ, 2016. 26(8), 327-337. https://doi.org/10.15421/40260850

5. Кібербезпека як важлива складова всієї системи захисту держави Міністерство оборони України. URL: https://www.mil.gov.ua/ukbs/kiberbezpeka-yak-vazhliva-skladova-vsiei-sistemi-zahistu-derzhavi.html

6. Обзор киберугроз 2020: результат пандемии (2020). URL: https://techexpert.ua/ru/cybersecuritycovid/

7. Трофименко О., Прокоп Ю., Логінова Н., \& Задерейко О. Кібербезпека України: аналіз сучасного стану. Захист інфрормації, 2019. 21(3), 150-157.https://doi.org/10.18372/2410-7840.21.13951

8. Бойко В.Д., Василенко М.Д., \& Кухаренко С.В. Кібербезпека в ЄС та країнах-членах: генезис та проблеми іï̈ підвищення. Інформаційна безпека людини, суспільства, держави, 2019. 3, 57-69. URL: http:// nbuv.gov.ua/ UJRN/iblsd_2019_3_8

9. Конституція України (1996). Верховна Рада України, 30. URL: https://zakon.rada.gov.ua/laws/ show/254\%D0\%BA/96-\%D0\%B2\%D1\%80\#Text

10. Закон України «Про інформацію» № 2657-XII (2020). URL: https://zakon.rada.gov.ua/laws/ main/265712\#Text

11. Закон України № 80/94-BP. Про захист інфрормації в інформаційно-телекомунікаційних системах. URL: https://zakon.rada.gov.ua/laws/show/80/94-\%D0\%B2\%D1\%80\#Text

12. Закон України № 2297-VI. 2021. Про захист персональних даних. URL: https://zakon.rada.gov. ua/laws/ show/2297-17\#Text

13. Стратегія кібербезпеки України. URL: https://www.rnbo.gov.ua/ua/Ukazy/417.html?PRINT

14. Закон України № 2163 VIII. 2021. Про основні засади забезпечення кібербезпеки України. URL: https:// zakon.rada.gov.ua/laws/show/2163-19\#Text

15. Закон України № 2469 VIII (2021). Про національну безпеку. URL: https://zakon.rada.gov.ua/laws/ show/2469-19\#Text

16. Постанова Кабінету Міністрів України № 373 . 2006. Про затвердження Правил забезпечення захисту інформації в інформаційних, телекомунікаційних та інформаційно-телекомунікаційних системах. URL: https:// zakon.rada.gov.ua/laws/show/373-2006-\%D0\%BF\#Text

17. Постанова Кабінету Міністрів України № 518 (2019). Про затвердження Загальних вимог до кіберзахисту об’єктів критичної інфрраструктури. Режим доступу: https://zakon.rada.gov.ua/laws/show/518-2019-\%D0\%BF\#n8

18. Указ Президента України № 242 (2016). Про Національний координаційний центр кібербезпеки. Режим доступу: https://www.president.gov.ua/documents/2422016-20141

19. Янковський О. Україні потрібна нова кіберстратегія. Українська правда. 2019. URL: https:// www.pravda. com.ua/rus/columns/2019/09/14/7226291/

20. Чибиряк М.С. \& Федоровська Н.В. Проблемні питання та шляхи вдосконалення законодавства України у сфері забезпечення кібербезпеки. 2017. URL: http://dspace.oduvs.edu.ua/ bitstream/123456789/491/1/ilovepdf_ com-57-58\%5B1\%5D.pdf

21. ДITM MHTУ став партнером CRDF GLOBAL (2021). URL: http://www.ditm.com.ua/crdf-global.

\section{REFERENCES:}

1. Valiushko, I. O. (2016). Kiberbezpeka Ukrainy: naukovi ta praktychni vymiry suchasnosti [Cybersecurity of Ukraine: scientific and practical dimensions of modernity]. Vìsnik Nacional'nogo tehničnogo universitetu Ukraïni «Kiïvs'kij politehničnij institut» Politologiâ, sociologiâ, pravo. (31/32), 117-124 https://doi.org/10.20535/23085053.20 16.3/4(31/32). 140496 [in Ukranian].

2. Bakalinska, O., \& Bakalinskyi, O. (2019). Pravove zabezpechennia kiberbezpeky v Ukraini [Legal support cybersecurity in Ukraine]. Pipryiemnytstvo, hospodarstvo i pravo. Entrepreneurship, Economy and Law. 9. 100-108. URL: https://doi. org/10.32849/2663-5313/2019.9.17 [in Ukranian].

3. Khobbi, Yu. (2020). Pravo liudyny na kiberbezpeku: problemy vyznachennia ta harantuvannia [The human right to cybersecurity: problems of definition and ensuring]. Yurydychnyi visnyk. Law herald, 2, 37-43. URL: https://doi. 
org/10.32837/yuv. v0i2.1701 [in Ukranian].

4. Gryciuk,Yu. I. (2016). Kiberinterventsiia ta kiberbezpeka Ukrainy: problemy ta perspektyvy yikh podolannia [CyberInterventionand Cyber Security of Ukraine: Problemsand Prospects of Overcoming Them].Naukovyi visnyk NLTU - Scientific bulletin of UNFU, 26(8),327-337. URL: https://doi.org/10.15421/40260850[inUkranian].

5. Kiberbezpeka yak vazhlyva skladova vsiiei systemy zakhystu derzhavy Ministerstvo oborony Ukrainy[Cybersecurity as an important component of theentire state defense system Ministry of Defense of Ukraine] (2018). Retrievedfromhttps://www. mil.gov.ua/ukbs/kiberbezpeka-yak-vazhliva-skladova-vsiei-sistemi-zahistu-derzhavi.html[inUkranian].

6. Obzor kyberuhroz 2020: rezultat pandemyy [Review of cyberthreats 2020: the result of a pandemic] (2020). Retrieved from https://techexpert.ua/ru/cybersecurity-covid/ [in Russian].

7.Trofymenko, O., Prokop, Yu., Lohinova, N., \& Zadereiko, O. (2019). Kiberbezpeka Ukrainy: analiz suchasnoho stanu [Cybersecurity of Ukraine: analysis of the current situation] Zakhyst informatsii - Security Research, 21(3),150-157. https://doi. org/10.18372/2410-7840.21.13951 [in Ukranian].

8. Boiko, V. D., Vasylenko, M. D., \& Kukharenko, S. V. (2019). Kiberbezpeka v YeS ta krainakh-chlenakh: henezys ta problemy y ii pidvyshchennia [Cybersecurity in the EU and member states: genesis and problems of improving It]. Informatsiina bezpeka liudyny, suspilstva, derzhavy - Information security of the person, society and state,3,57-69. Retrieved fromhttp://nbuv.gov.ua/ UJRN/iblsd_2019_3_8[inUkranian].

9. Konstytutsiia Ukrainy [The Constitution of Ukraine] (1996). Verkhovna Rada Ukrainy - Verkhovna Rada of Ukraine, 30. Retrieved from https://zakon.rada.gov.ua/laws/show/254\%D0\%BA/96-\%D0\%B2\%D1\%80?lang=en\#Text [inUkranian].

10. Zakon Ukrainy № 2657-XII (2020). Pro informatsiiu [On information]. Retrieved from https://zakon.rada.gov. ua/laws/ main/2657-12\#Text [inUkranian].

11. Zakon Ukrainy № 80/94-VR (2020). Pro zakhyst informatsii v informatsiino-telekomunikatsiinykh systemakh[On protection of information in automated systems]. Retrieved from https://zakon.rada.gov.ua/laws/show/80/94\%D0\%B2\%D1\%80?lang=en\#Text [inUkranian].

12. Zakon Ukrainy № 2297-VI (2021).Pro zakhyst personalnykh danykh[On protection of personal data].Retrievedfromhttps://zakon.rada.gov.ua/laws/show/2297-17\#Text[inUkranian].

13. Stratehiia kiberbezpeky Ukrainy[Cybersecurity strategy of Ukraine](2016). Retrieved from https://www.rnbo. gov.ua/ua/ Ukazy/417.html?PRINT[inUkranian].

14. Zakon Ukrainy № 2163 VIII (2021). Pro osnovni zasady zabezpechennia kiberbezpeky Ukrainy [On the basic principles of cybersecurity in Ukraine Law of Ukraine].Retrieved from https://zakon.rada.gov.ua/laws/show/216319\#Text [inUkranian].

15. Zakon Ukrainy № 2469 VIII (2021). Pro natsionalnu bezpeku [About national security] Retrieved from https:// zakon.rada.gov.ua/laws/show/2469-19\#Text [inUkranian].

16. Postanova Kabinetu Ministriv Ukrainy № 373 (2006). Pro zatverdzhennia pravyl zabezpechennia zakhystu informatsii $v$ informatsiinykh, telekomunikatsiinykh ta informatsiino-telekomunikatsiinykh systemakh [About the statement of rules of maintenance of protection of the information in information, telecommunication and informationtelecommunication systems]. Retrieved from https://zakon.rada.gov.ua/laws/show/373-2006-\%D0\%BF\#Text [inUkranian].

17. Postanova Kabinetu Ministriv Ukrainy № 518 (2019). Pro zatverdzhennia Zahalnykh vymoh do kiberzakhystu obiektiv krytychnoi infrastruktury[About the statement of the General requirements to cyber protection of objects of critical infrastructure].Retrievedfromhttps://zakon.rada.gov.ua/laws/show/518-2019-\%D0\%BF\#n8 [inUkranian].

18. UkazPrezydentaUkrainy№242(2016).Pro Natsionalnyi koordynatsiinyi tsentr kiberbezpeky[About the National Cyber Security Coordination Center].Retrieved from https://www.president.gov.ua/documents/2422016-20141 [inUkranian].

19. Yankovskyi, O. (2019). Ukraini potribna nova kiberstratehiia [Ukraine needs a new cyberstrategy]. Ukrainska pravda - Ukrayinska Pravda. Retrieved from https://www.pravda.com.ua/rus/columns/2019/09/14/7226291/[inUkranian].

20. Chybyriak, M. S. \& Fedorovska, N. V.(2017). Problemni pytannia ta shliakhy vdoskonalennia zakonodavstva Ukrainy u sferi zabezpechennia kiberbezpeky[Problematic issues and ways to improve Ukrainian legislation in the field of cybersecurity]. Retrieved from http://dspace.oduvs.edu.ua/bitstream/123456789/491/1/ilovepdf_com-5758\%5B1\%5D.pdf [inUkranian].

21. DITM MNTU stav partnerom CRDF GLOBAL [DITM MNTU became a partner of CRDF GLOBAL] (2021). Re trieved from http://www.ditm.com.ua/crdf-global [in Ukranian]. 